\title{
Implication of Social Restrictions on Covid-19 Pandemic Towards Dengue Control: Literature Review
}

\author{
Wahyu Widyantoro ${ }^{1 *}$, Nurjazuli ${ }^{1}$, and Yusniar Hanani Darundiati ${ }^{1}$ \\ ${ }^{1}$ Magister of Environmental Health, Public Health Faculty, Diponegoro University, \\ Semarang, Indonesia
}

\begin{abstract}
The 2019 coronavirus (COVID-19) outbreak was first discovered in Wuhan, China, and was declared a pandemic by the World Health Organization (WHO) on March 11, 2020. In dealing with the COVID-19 pandemic, various countries have implemented social restrictions on their citizens. Social limits due to the COVID-19 pandemic have caused different life effects that have never occurred. This phenomenon will affect the transmission of existing diseases such as dengue fever. This study aims to determine the impact of social restrictions on dengue transmission and indicators of dengue. This research method is a systematic literature review, is a literature review by synthesizing 294 selected 12 articles from the Pubmed.gov database. The literature shows that social restrictions during the COVID-19 pandemic hurt the supervision and control of dengue. The increase in the dengue indicator, namely the density of mosquitoes, increased due to the termination of the control program. Human movement is a critical behavioural factor in many vectorborne disease systems because it affects vector exposure and pathogen transmission. The aspect of community mobility also reduces dengue cases during social distancing due to COVID-19.
\end{abstract}

\section{Introduction}

The 2019 coronavirus disease outbreak (COVID-19) was first identified in Wuhan, China, in December 2019. Coronavirus disease 2019 (COVID-19) is a respiratory disease caused by severe acute respiratory syndrome coronavirus 2 (SARS-CoV-2). COVID-19 was declared a pandemic by the World Health Organization on March 11, 2020([1].)Most people infected with SARS-CoV-2 did not show symptoms or exhibit non-specific flu-like symptoms, such as fever, headache, fatigue, and dry cough([2].) COVID-19 can be transmitted mainly through contact; transmission occurs through droplets from the nose or mouth of a person with COVID-19 while breathing or coughing ([3].)The transmission of COVID-19 is very fast until April 10, 2021. The cases of COVID-19 worldwide reached 134 million, with the number of deaths reaching 2.9 million [4].

Responding to the COVID-19 pandemic, many countries in the world must implement social restrictions by limiting the mobility of citizens and social distancing [5]. Social

* Corresponding author:Kangbeyes@gmail.com 
restrictions can demonstrate success in containing the spread of the COVID-19 outbreak and flattening the curve in many countries[6],[7].Different countries take different approaches to social distancing with varying limitations, compliance, target populations, and duration of social restrictions[8].Social restriction refers to the deliberate reduction of close person-to-person contacts, such as closing schools and workplaces. These measures help stem the 2019 coronavirus disease (COVID-19) but hurt social structures and public health [9].

Dengue fever is an endemic disease caused by arbovirus continuously in several tropical areas around the world. [10] In the world, an estimated 390 million cases of dengue fever[11].The disease is affected by rainfall, temperature, and urbanization. Demographic and social changes such as population growth and modern transportation have significantly contributed to the increased incidence and geographic spread of dengue fever activity[12].Population density, vector distribution, and the dengue virus can affect the potential for dengue transmission. Biotic, abiotic, and social environmental factors become complex in the prevention of DHF. Breaking the life cycle of mosquito vectors using biological, physical, and chemical approaches focuses on preventing and preventing DHF[13].The density of vectors includes house index (HI), container index (CI), breteau index (BI), which are indicators of vector presence in water containers inside or outside the house[14].

Vector Vector control remains the primary method in preventing dengue disease. Some efforts are made through environmental intervention, chemical control using insecticides and larvicides, and biological control. Vector control strategy, which aims to reduce the reproduction and reproduction of Aedes sp. mosquitoes through environmental intervention, is also essential. The method is emptying the water container, cleaning the breeding grounds for Aedes sp., shutting down water, and implementing promotion and community empowerment[15]. Environmental intervention is a sustainable and safe method because the risk of contamination and environmental toxicity is limited. Dengue control is becoming more challenging due to urbanization, population growth, increased international travel, and the lack of vector control programs in dengue-endemic countries[16].

The COVID-19 pandemic adds to the health burden for countries still dealing with endemic dengue fever[17]. The purpose of writing this literature review is to systematically review the implications of social restrictions for the COVID-19 pandemic on DHF control.

\section{Methods}

The writing of this review follows the guidelines for a systematic review as stated in PRISMA[18].This writing is a literature review using secondary studies from various journals indexed by Pubmed.gov. This research was conducted in March and April 2021. Articles included through an update of the initial searches until 01.05.21 are presented in the discussion section.

A range of search terms was used in combinations to identify all relevant studies. The search terms included (a) disease-specific terms: COVID-19, severe acute respiratory syndrome coronavirus 2, coronavirus, SARS-CoV-2, Dengue, Dengue hemorrhagic fever, Dengue hemorrhagic fever, DHF, and DF, (b) vector-specific terms: Aedes, Aedes aegypti, Aedes albopictus, Ae. Egypt, and Ae. albopictus, and (c) implication specific terms: Social Discanting, pandemic movement control, MCO, Large-scale Social Restrictions, PSBB, Lockdown, quarantine measures, Isolation, quarantine, and community containment. Screened by applying inclusion and exclusion criteria to refine the study, then the manuscripts of the remaining articles were screened together for inclusion in the review. 
Twelve articles were used as references for literature review using synthesis narrative techniques as can be seen in Figure 1.

The The article inclusions used: (i) In the Pubmed.gov database, (ii) Publication year 2020-2021, (iii) Has the theme of COVID-19 research, (iv) Has a relationship with dengue vector control. The article exclusion criteria used were not published in Pubmed but had the theme COVID-19 and DHF control.

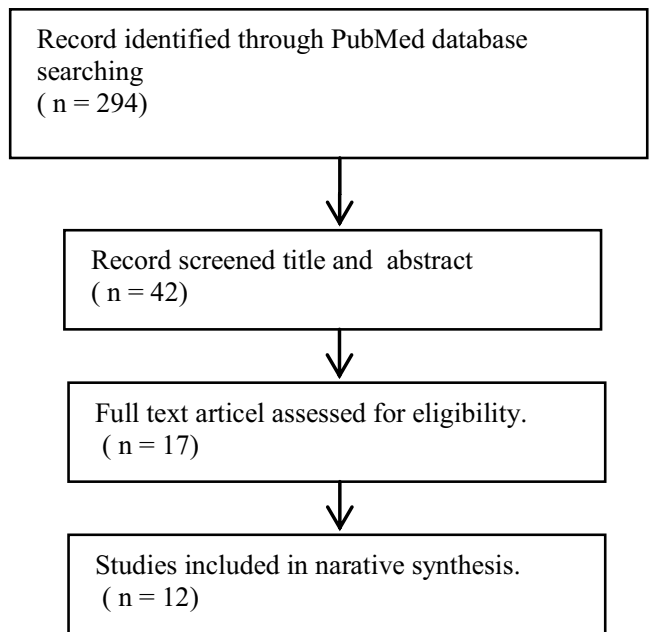

Fig. 1. Flow chart of literature search and selections studies.

\section{Results and discussion}

\subsection{Identification and synthesis of articles}

All literature articles from Pudmed.gov with keywords (a) disease-specific terms: COVID-19, severe acute respiratory syndrome coronavirus 2, coronavirus, SARS-CoV-2, Dengue, Dengue hemorrhagic fever, Dengue hemorrhagic fever, DHF, and DF, (b) vectorspecific terms: Aedes, Aedes aegypti, Aedes albopictus, Ae. aegypti, and Ae. albopictus, and (c) implication specific terms: Social Discanting, pandemic movement control, MCO, Large-scale Social Restrictions, PSBB, Lockdown, quarantine measures, Isolation, quarantine, and community containment. Two hundred ninety-four (294) articles were related to vector control to social restrictions due to COVID-19. This literature contains nine studies and also includes viewpoints ([19],)Brief report, sort communication ([20],)perspective ([21].)The study area comprises high-risk countries for DHF except for Africa, found eight from Asia covering (Singapore, Malaysia, Thailand, and India) while the other four articles from Latin America include (Brazil, Mexico, and Colombia). 
Table 1. Article synthesis results.

\begin{tabular}{|c|c|c|c|c|}
\hline No & Researcher & Findings & Location & Reference \\
\hline 1 & $\begin{array}{l}\text { Daniel } \\
\text { Reegan, } \\
\text { Appadurai et } \\
\text { al. }\end{array}$ & $\begin{array}{l}\text { 1) The density of immature Aedes mosquitoes was } \\
\text { found to increase drastically during the } \\
\text { lockdown survey because the dengue vector } \\
\text { control program was stopped. } \\
\text { 2) High larval and Pupal index after one month of } \\
\text { lockdown compared to the pre-lockdown index } \\
\text { in the two surveyed regions in the Indian City } \\
\text { of Bengaluru. } \\
\text { 3) House Index was observed to increase slightly } \\
\text { during the first COVID-19 lockdown survey } \\
\text { (after one week of lockdown). } \\
\text { 4) Correspondingly, House Index significantly } \\
\text { improved during the second survey of the } \\
\text { COVID-19 lockdowns (after one month of } \\
\text { lockdown). Likewise, the Breteau Index and the } \\
\text { Pupal Index also significantly increased after a } \\
\text { month's lockdown. }\end{array}$ & India & {$[22]$} \\
\hline 2 & $\begin{array}{l}\text { Rahim, } \\
\text { Mohd Hafiz } \\
\text { et al. }\end{array}$ & $\begin{array}{l}\text { The results showed that during of Movement } \\
\text { Control Order in Peninsular Malaysia, 11,242 } \\
\text { cases of DHF were reported. The daily trend of } \\
\text { DHF cases shows a decrease from } 7,268 \text { cases } \\
\text { that occurred before Movement Control Order } \\
\text { to } 4662 \text { cases of DHF that occurred during the } \\
\text { initial } 14 \text { days of the COVID-19 pandemic } \\
\text { (namely Movement Control Order I) to } 3,075 \\
\text { cases that occurred during MCO II. and } 3505 \\
\text { cases of scarlet fever were recorded during } \\
\text { Movement Control Order III. The decline in } \\
\text { this pattern is not solely based on Movement } \\
\text { Control Order. Therefore it is necessary to carry } \\
\text { out further investigations after considering the } \\
\text { influencing factors. }\end{array}$ & Malaysia & [23] \\
\hline 3 & $\begin{array}{l}\text { Lim, Jue Tao } \\
\text { et al. }\end{array}$ & $\begin{array}{l}\text { The reduction of } 4,8 \text { dengue fever problems per } \\
\text { age group among migrant workers was due to } \\
\text { the quarantine policy, matching a total } \\
\text { reduction of near } 432 \text { dengue fever problems } \\
\text { reported over } 10 \text { weeks. There was an increase } \\
\text { of } 14.5 \text { cases of dengue fever per age group in } \\
\text { the universal working population, which } \\
\text { corresponds to a total increase of near } 1.450 \\
\text { cases of dengue fever reported in the same } \\
\text { period. There is an expected reduction in the } \\
\text { relative risk of dengue fever transmission for } \\
\text { the migrant working population at } 0.635 \text { due to } \\
\text { the quarantine policy and an increased relative } \\
\text { risk for the universal working population due to } \\
\text { the social distancing policy at } 0.685 \text {. }\end{array}$ & $\begin{array}{l}\text { Singapur } \\
\mathrm{e}\end{array}$ & [24] \\
\hline
\end{tabular}




\begin{tabular}{|c|c|c|c|c|}
\hline 4 & $\begin{array}{l}\text { Vicente, } \\
\text { Creuza } \\
\text { Rachel et al }\end{array}$ & $\begin{array}{l}\text { 1) An increase in cases of increasing COVID-19 } \\
\text { and dengue fever simultaneously affects the } \\
\text { health system } \\
\text { 2) This study proves the impact of simultaneous } \\
\text { epidemics beyond socio-economic losses and is } \\
\text { responsible for many deaths in Espírito Santo } \\
\text { State, with many municipalities affected by at } \\
\text { least two concurrent epidemics, jeopardizing } \\
\text { the health system response. }\end{array}$ & Brazil & {$[25]$} \\
\hline 5 & $\begin{array}{l}\text { Ong, Song- } \\
\text { Quan et al. }\end{array}$ & $\begin{array}{l}\text { The incidence of dengue fever decreased } \\
\text { significantly to a greater extent during the phase } \\
1 \text { lockdown, with a negative gradient } 3.2 \text {-fold } \\
\text { steeper than the trend observed in previous } \\
\text { years and } 6.5 \text {-fold. Steeper than simulations, } \\
\text { suggesting that control of population } \\
\text { movements has reduced dengue transmission. }\end{array}$ & Malaysia & {$[26]$} \\
\hline 6 & $\begin{array}{l}\text { Olive M-M, } \\
\text { Baldet T, } \\
\text { Devillers J, } \\
\text { Fite J, Paty } \\
\text { M-C, Paupy } \\
\text { C, et al. }\end{array}$ & $\begin{array}{l}\text { Social limitations genuinely risk the viability of } \\
\text { vector control, particularly friendly assembly } \\
\text { crusades and the showering of preventive bug } \\
\text { sprays in private spaces. Hence, inability to } \\
\text { appropriately execute different vector control } \\
\text { mediations can prompt the diminished generally } \\
\text { viability and an expanded danger of existing } \\
\text { vector-borne sicknesses. Hence, the wellbeing } \\
\text { local area and policymakers should foster } \\
\text { proactive strategies and designate satisfactory } \\
\text { assets to forestall and deal with the increment in } \\
\text { dengue fever in the new time of Coronavirus. }\end{array}$ & Brazil & [19] \\
\hline 7 & $\begin{array}{l}\text { Lim, Jue Tao } \\
\text { et al. }\end{array}$ & $\begin{array}{l}\text { Social removing measures pointed toward } \\
\text { checking the spread of SARS-CoV-2 stay a } \\
\text { basic general wellbeing mediation. Little is } \\
\text { thought about the extra effect of decreased } \\
\text { versatility on the danger of other irresistible } \\
\text { illnesses. They are utilizing contrasts in the } \\
\text { quantity of dengue cases prior and then } \\
\text { afterward embracing Social separating } \\
\text { measures and taking advantage of the } \\
\text { heterogeneity in Friendly removing treatment } \\
\text { impacts among various age bunches in } \\
\text { Singapore to recognize overflow impacts of SD } \\
\text { measures. The Social separating strategy } \\
\text { prompted an expansion of over } 37.2 \% \text { instances } \\
\text { of dengue fever from standard. Extra measures } \\
\text { to preemptively relieve the danger of other } \\
\text { irresistible infections ought to be considered } \\
\text { prior to carrying out/re-execution of the SARS- } \\
\text { CoV-2 Social removing measures. }\end{array}$ & $\begin{array}{l}\text { Singapur } \\
\text { a }\end{array}$ & {$[27]$} \\
\hline 8 & $\begin{array}{l}\text { Cardona- } \\
\text { Ospina, } \\
\text { Jaime A et } \\
\text { al. }\end{array}$ & $\begin{array}{l}\text { Intensive interventions, especially in certain } \\
\text { areas, can help prevent dengue incidence at a } \\
\text { lower level. Other arboviral diseases such as } \\
\text { Chikungunya have caused epidemics recently in } \\
\text { Colombia, with cases of co-infection being } \\
\text { reported with the dengue virus. Because } \\
\text { COVID-19 and dengue can be fatal, especially } \\
\text { in patients with comorbid chronic illnesses, } \\
\text { overlapping infections and concomitant events } \\
\text { can increase the number of patients requiring }\end{array}$ & columbia & {$[20]$} \\
\hline
\end{tabular}




\begin{tabular}{|c|c|c|c|c|}
\hline & & $\begin{array}{l}\text { intensive care and mechanical ventilation of } \\
\text { Columbia }\end{array}$ & & \\
\hline 9 & $\begin{array}{l}\text { Rahman, Md } \\
\text { Mostafizur, } \\
\text { et al. }\end{array}$ & $\begin{array}{l}\text { The symptoms of COVID-19 and dengue have } \\
\text { several things in common. Therefore, detection } \\
\text { and isolation may be a real challenge for several } \\
\text { interventions to strengthen health facilities, } \\
\text { including proposing community-based health } \\
\text { facilities, improving online-based health } \\
\text { support systems, and universal health insurance } \\
\text { for every citizen, and increasing health support } \\
\text { personnel, sustainable awareness development } \\
\text { programs. About hygienic practices, ensuring } \\
\text { their appropriateness. sanitation facilities, } \\
\text { household, and community-based water } \\
\text { management }\end{array}$ & $\begin{array}{l}\text { Banglade } \\
\text { sh }\end{array}$ & [28] \\
\hline 10 & $\begin{array}{l}\text { Dantés, } \\
\text { Héctor } \\
\text { Gómez, et al. }\end{array}$ & $\begin{array}{l}\text { Fear of transmission by COVID-19 prevents } \\
\text { people with the arboviral disease from seeking } \\
\text { treatment, which can lead to an increase in } \\
\text { severe cases and could disrupt vector control } \\
\text { programs due to residents' reluctance to open } \\
\text { their doors to health workers. Promoting intense } \\
\text { community participation and incorporating } \\
\text { long-term innovations in vector control offers } \\
\text { new opportunities for control. }\end{array}$ & Mexico & [21] \\
\hline 11 & $\begin{array}{l}\text { Lim, Jue } \\
\text { Tao, et al. }\end{array}$ & $\begin{array}{l}\text { Social distancing and increased time spent in } \\
\text { residence can lead to a higher incidence of } \\
\text { vector-borne disease. The adoption of social } \\
\text { distancing policies may result in under-reported } \\
\text { dengue cases as individuals may be less willing } \\
\text { to leave home and seek professional medical } \\
\text { care. Inadequate reporting could also result } \\
\text { from the additional burden of COVID-19 on the } \\
\text { health system, which reduces the number of } \\
\text { non-COVID-19 patients seeking treatment. }\end{array}$ & Thailand & [29] \\
\hline 12 & Juan $P$, et al & $\begin{array}{l}\text { Syndemic is a meeting of two or more diseases } \\
\text { at the same time and space. In Mexico, the } \\
\text { dengue fever epidemic is active and } \\
\text { predominates in the Pacific and Gulf of Mexico } \\
\text { regions; meanwhile, the COVID-19 epidemic } \\
\text { affects the same areas as dengue fever. Given } \\
\text { that this disease has many clinical } \\
\text { manifestations in areas endemic to tropical } \\
\text { diseases, it is crucial to carefully evaluate } \\
\text { patients who consult for fever in order to } \\
\text { establish the correct diagnosis at the right time. } \\
\text { Laboratory tests are required to make the } \\
\text { appropriate measurements for each patient. In } \\
\text { Mexico, the risk of COVID-19 and dengue } \\
\text { fever syndrome is high, which can cause the } \\
\text { health system to collapse. The southeastern } \\
\text { states and those bordering the Pacific deserve } \\
\text { special attention because they present } \\
\text { geographic, environmental, and climatic } \\
\text { conditions that support the rapid spread of } \\
\text { dengue and COVID-19. The simultaneous } \\
\text { infection will worsen the epidemiological } \\
\text { situation, complicating the diagnosis, control, }\end{array}$ & Mexico & [30] \\
\hline
\end{tabular}




\subsection{Discussion}

In times of social restrictions, everyone is required to stay at home. Dengue fever transmission in and around the home is considered the driving factor for the dengue fever outbreak. Mobilization of people on a local scale, allocating different amounts of time to locations regularly. affect the individual risk of dengue virus infection [31]. This consistent increase in the growth rate of DHF, in addition to a significant increase in the cumulative number of infected cases in the lockdown scenario. This drastic impact results from this increase in the likelihood that infected mosquitoes will bite large numbers of humans due to increased local population density and reduced human mobility from the lockdown [32]. Cases of dengue fever are more severe than chikungunya under any circumstances, even though they share the same vector, Aedes aegypti [32].

The results showed that social restrictions were associated with an increase in DHF cases reported in Singapore. One of the main avenues that could explain this result is the increase in time spent at home addresses due to social distancing policies and the tendency for dengue infection to occur at home rather than at office addresses in Singapore[24].Although workplace infections may surface, it was found that, in many areas, the place of residence is the most common site of vector-borne disease infection rather than the workplace. The concentration of vector breeding sites in the vicinity of residential areas further increases the risk of transmission in these sites compared to workplaces. Due to the shift in working patterns into homes with naturally ventilated spaces, which do not protect during biting periods during the day, these pathways are driven by social distancing policies that collectively incorporate risk factors for dengue fever transmission [33].

However, different things in Malaysia do not significantly affect dengue transmission due to social restrictions. [34])country-to-country comparisons in the impact of social distancing policies on reported dengue fever problems due to comparisons in workplace structures, increased risk of arbovirus transmission from social distance primarily through increased vector exposure in increased time spent in residence. Demonstrating the need to control positional influence on the risk of dengue fever transmission in new population mix-ups such as those contained in social distancing policies [29].

The effectiveness of restrictive policies as a public health intervention to reduce the spread of the COVID-19 disease is known to reduce human contact by increasing time spent in residence. The increased time spent in residence during the day and their exposure to vectors could also influence patterns of vector-borne disease transmission - but in the opposite direction. Increasing the time spent at a site increases the risk of vector-borne disease transmission despite vector density - suggesting that house-to-house movement of humans underlies the spatial pattern of DENV incidence, leading to striking heterogeneity in transmission rates. At the collective level, transmission appears to be shaped by social connections because routine movements between the same places, such as the homes of family and friends, are often similar for infected individuals and their contacts. Thus, the normal movement of humans from house to house does indeed play a vital role in the spread of these vector-borne pathogens on subtle spatial scales. These findings have important implications for preventing dengue fever, challenging the appropriateness of current vector control approaches. We argue that reexamining the existing paradigm regarding the spatial dynamics of DENV and other vector-borne pathogens, particularly the 
importance of human movement, will lead to improvements in disease prevention $[35,36]$.

\section{Conclusion}

The implications of social restrictions on DHF control in the COVID-19 pandemic harm the supervision and control of DHF. The increase in the DHF indicator, namely the density of mosquitoes, increased due to the termination of the control program. Human movement is a critical behavioural factor in many vector-borne disease systems because it affects vector exposure and pathogen transmission. The factor of community mobility has also shown an effect on reducing dengue cases during social restrictions due to COVID-19.

\section{References}

1. World Helath Organization. Coronavirus disease (COVID-19) (2019) Retrivied from: https://www.who.int/emergencies/diseases/novel-coronavirus-2019

2. B. Joob, V. Wiwanitkit. COVID-19 can present with a rash and be mistaken for dengue, Journal of the American Academy of Dermatology, 82 (2020) https://doi.org/10.1016/j.jaad.2020.03.036

3. A. Athena, E. Laelasari, T. Puspita. Implementation of disinfection in preventing the transmission of covid-19 and potential risks to health in indonesia. J Ekol Kesehat. 19 (1):1-20 (2020) https://doi.org/10.22435/jek.v19i1.3146

4. WHO. WHO Coronavirus Disease (COVID-19). Retrivied from: https://covid19.who.int/\%0Ahttps://covid19.who.int/\%0Ahttps:/covid19.who.int/?gcli $\mathrm{d}=$ CjwKCAjwnK36BRBVEiwAsMT8WJ3y00_BUzvrLsvbl3uthuoTH_Occ45gyEUbp YRyEqAzll3aZB6TYxoCcM0QAvD_BwE

5. A. Wilder-Smith, Y. Bar-Yam, D. Fisher. Lockdown to contain COVID-19 is a window of opportunity to prevent the second wave, Journal of Travel Medicine. Oxford University Press, 27 (2021) https://pubmed.ncbi.nlm.nih.gov/32478396/

6. H. Lau, V. Khosrawipour, P. Kocbach, A. Mikolajczyk, J.Schubert, J. Bania et al. The positive impact of lockdown in Wuhan on containing the COVID-19 outbreak in China, J Travel Med. 27 (3) : 1-7 (2021) https://pubmed.ncbi.nlm.nih.gov/32181488/

7. M. Pachetti, B. Marini, F. Giudici, F. Benedetti, S. Angeletti, M. Ciccozzi et al. Impact of lockdown on Covid-19 case fatality rate and viral mutations spread in 7 countries in Europe and North America, J Transl Med. 18 (1) (2020) https://pubmed.ncbi.nlm.nih.gov/32878627/

8. Q. Zheng, F. K. Jones, S. V. Leavitt, L. Ung, A. B. Labrique, D. H. Peters et al. HITCOVID, a global database tracking public health interventions to COVID-19, Sci Data. 7 (1). https://pubmed.ncbi.nlm.nih.gov/32855428/

9. J. Ryan, J. Okeibunor, A. Talisuna, C. S. Wiysonge. Setting up and relaxation of public health social and physical distancing measures for covid-19: A rapid review, Pan Afr Med J. 35: 1-5 (2020) https://pubmed.ncbi.nlm.nih.gov/33623600/

10. J. P. Messina, O. J. Brady, N. Golding, M. U. G. Kraemer, G. R. W. Wint, S. E. Ray et al. The current and future global distribution and population at risk of dengue. Nat Microbiol. 4 (9) : 1508-15 (2019) /pmc/articles/PMC6784886/?report=abstract

11. S. Bhatt, P. W. Gething, O. J. Brady, J. P. Messina, A. W. Farlow, C. L. Moyes et al. The global distribution and burden of dengue, Nature, 496 (7446) : 504-507 (2013) /pmc/articles/PMC3651993/?report=abstract 
12. D. J. Gubler. Epidemic dengue/dengue hemorrhagic fever as a public health, social and economic problem in the 21st century, Trends Microbiol. 10, 100-103 (2002) https://pubmed.ncbi.nlm.nih.gov/11827812/

13. A. Sanyaolu. Global epidemiology of dengue hemorrhagic fever: An update. J Hum Virol Retrovirology. 5 (6), (2017) http://medcraveonline.com

14. S. Runge-Ranzinger, A. Kroeger, P. Olliaro, P. J. McCall, G. Sánchez Tejeda, L. S. Lloyd et al. Dengue Contingency Planning: From Research to Policy and Practice, PLoS Negl Trop Dis. 10 (9), (2016)

15. World Health Organization. Treatment, Prevention And Control Treatment, Prevention And Control 2012-2020 (2012) Retrivied from: www.who.int/neglected_diseases/en

16. C. Buhler, V. Winkler, S. Runge-Ranzinger, R. Boyce, O. Horstick. Environmental methods for dengue vector control - A systematic review and meta-analysis, PLoS $\begin{array}{llll}\text { Neglected } & \text { Tropical } & \text { Diseases. }\end{array}$ https://pubmed.ncbi.nlm.nih.gov/31295250/

17. D. $\mathrm{Wu}, \mathrm{J} . \mathrm{Lu}, \mathrm{Q}$. Liu, X. Ma, W. He. To alert coinfection of COVID-19 and dengue virus in developing countries in the dengue-endemic area, Infection Control and Hospital Epidemiology, Cambridge University Press, 41 (2020) https://doi.org/10.1017/ice.2020.193

18. A. Liberati, D. G. Altman, J. Tetzlaff, C. Mulrow, P. C. Gøtzsche, J. P. A. Ioannidis et al. The PRISMA statement for reporting systematic reviews and meta-analyses of studies that evaluate healthcare interventions: explanation and elaboration. BMJ, 339 (2009) http://www.bmj.com/

19. M-M. Olive, T. Baldet, J. Devillers, J. Fite, M-C. Paty, C. Paupy et al. The COVID-19 pandemic should not jeopardize dengue control, PLoS Negl Trop Dis, 14 (9), (2020) https://dx.plos.org/10.1371/journal.pntd.0008716

20. J. A. Cardona-Ospina, K. Arteaga-Livias, W. E. Villamil-Gómez, C. E. Pérez-Díaz, D. Katterine Bonilla-Aldana, Á. Mondragon-Cardona et al. Dengue and COVID-19, overlapping epidemics? An analysis from Colombia, J Med Virol, 93 (1) : 522-527 (2021) https://pubmed.ncbi.nlm.nih.gov/32558962/

21. H. G. Dantés, P. Manrique-Saide, G. Vazquez-Prokopec, F. C. Morales, J. B. Siqueira Junior, F. Pimenta et al. Prevention and control of aedes transmitted infections in the post-pandemic scenario of COVID-19: Challenges and opportunities for the Region of the Americas, Mem Inst Oswaldo Cruz. (2020) https://pubmed.ncbi.nlm.nih.gov/32785481/

22. A. Daniel Reegan, M. Rajiv Gandhi, A. Cruz Asharaja, C. Devi, S. P. Shanthakumar. COVID-19 lockdown: impact assessment on Aedes larval indices, breeding habitats, effects on vector control programme and prevention of dengue outbreaks. Heliyon, 6 (10), (2020) https://pubmed.ncbi.nlm.nih.gov/33043162/

23. M. H. Rahim, N. C. Dom, S.N. S. Ismail, A. A.Mulud, S. Abdullah, B. Pradhan. The impact of novel coronavirus (2019-nCoV) pandemic movement control order (MCO) on dengue cases in Peninsular Malaysia, One Heal, 12 (2021) https://pubmed.ncbi.nlm.nih.gov/33553566/

24. J. T. Lim, B. L. Dickens, J. Ong, J. Aik, V. J. Lee, A. R. Cook et al. Decreased dengue transmission in migrant worker populations in Singapore attributable to SARS-CoV-2 quarantine measures. J Travel Med. $28 \quad$ (2), (2021) https://pubmed.ncbi.nlm.nih.gov/33274384/

25. C. R. Vicente, T. C. C. da Silva, L. D. Pereira, A. E. Miranda. Impact of concurrent epidemics of dengue, chikungunya, zika, and covid-19. Rev Soc Bras Med Trop, 54 
(2021) https://pubmed.ncbi.nlm.nih.gov/33656154/

26. S. Q. Ong, H. Ahmad, A. M. M. Ngesom. Implications of the COVID-19 lockdown on dengue transmission in Malaysia. Infect Dis Rep. 13(1) (2021) https://pubmed.ncbi.nlm.nih.gov/33562890/

27. J. T. Lim, L. Z. X. Chew, E. L.W. Choo, B. S. L. Dickens, J. Ong, J. Aik et al. Increased Dengue Transmissions in Singapore Attributable to SARS-CoV-2 Social Distancing Measures. J Infect Dis. 223(3):399-402 (2021) https://pubmed.ncbi.nlm.nih.gov/33000172/

28. M. M. Rahman, M. Bodrud-Doza, M. Shammi, A. R. Md Towfiqul Islam, A. P. Moniruzzaman Khan. COVID-19 pandemic, dengue epidemic, and climate change vulnerability in Bangladesh: Scenario assessment for strategic management and policy implications. Environ Res, 192 (2021) https://pubmed.ncbi.nlm.nih.gov/33069704/

29. J. T. Lim, B.S. L. Dickens, L. Z. X. Chew, E. L. W. Choo, J. R. Koo, J. Aik et al. Impact of SARS-CoV-2 interventions on dengue transmission, PLoS Negl Trop Dis. 14 (10) : 1-17 (2020) https://pubmed.ncbi.nlm.nih.gov/33119609/

30. J. P. S. de la Cruz, C. A. Tovilla-Zárate, D. L. González-Morales, T. B. GonzálezCastro. Riesgo de sindemia de COVID-19 y fiebre del dengue en el sur de México, Gac Med Mex.156 (5) : 460-464 (2020)

31. S. T. Stoddard, A. C. Morrison, G. M. Vazquez-Prokopec, V. P. Soldan, T. J. Kochel, $\mathrm{U}$. Kitron et al. The role of human movement in the transmission of vector-borne pathogens, PLoS Negl Trop Dis. 3 (7) : e481 (2009) www.plosntds.org

32. A. Jindal, S. Rao. Lockdowns to contain COVID-19 increase risk and severity of mosquito-borne disease outbreaks [Internet]. medRxiv (2020) https://doi.org/10.1101/2020.04.11.20061143

33. S. Swain, M. Bhatt, D. Biswal, S. Pati, R. J. Soares Magalhaes. Risk factors for dengue outbreaks in Odisha, India: A case-control study, J Infect Public Health. 13 (4) : 625-631 (2020) https://pubmed.ncbi.nlm.nih.gov/31537510/

34. S. Abdullah, A. A. Mansor, N. N. L. M.Napi, W. N. W. Mansor, A. N. Ahmed, M. Ismail et al. Air quality status during 2020 Malaysia Movement Control Order (MCO) due to 2019 novel coronavirus (2019-nCoV) pandemic, Sci Total Environ. 729 (2020) https://pubmed.ncbi.nlm.nih.gov/32353722/

35. S. T. Stoddard, B. M. Forshey, A. C. Morrison, V. A. Paz-Soldan, G. M. VazquezProkopec, H. Astete et al. House-to-house human movement drives dengue virus transmission, Proc Natl Acad Sci U S A. 110 (3) : 994-999 (2003) https://pubmed.ncbi.nlm.nih.gov/23277539z

36. K. L. Schaber, T. A. Perkins, A. L. Lloyd, L. A. Waller, U. Kitron, V. A. Paz-Soldan et al. Disease-driven reduction in human mobility influences human-mosquito contacts and dengue transmission dynamics, PLoS Comput Biol 17 (1), (2021) https://pubmed.ncbi.nlm.nih.gov/33465065/ 